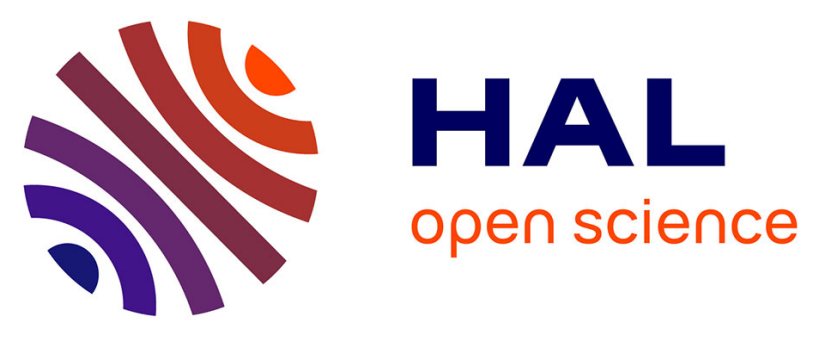

\title{
Carbon Dioxide Reduction to Methanol with a Molecular Cobalt-Catalyst-Loaded Porous Carbon Electrode Assisted by a CIGS Photovoltaic Cell
}

Ruwen Wang, Etienne Boutin, Nicolas Barreau, Fabrice Odobel, Julien Bonin, Marc Robert

\section{To cite this version:}

Ruwen Wang, Etienne Boutin, Nicolas Barreau, Fabrice Odobel, Julien Bonin, et al.. Carbon Dioxide Reduction to Methanol with a Molecular Cobalt-Catalyst-Loaded Porous Carbon Electrode Assisted by a CIGS Photovoltaic Cell. ChemPhotoChem, In press, 10.1002/cptc.202100035 . hal-03266423

\section{HAL Id: hal-03266423 \\ https://hal.science/hal-03266423}

Submitted on 21 Jul 2021

HAL is a multi-disciplinary open access archive for the deposit and dissemination of scientific research documents, whether they are published or not. The documents may come from teaching and research institutions in France or abroad, or from public or private research centers.
L'archive ouverte pluridisciplinaire HAL, est destinée au dépôt et à la diffusion de documents scientifiques de niveau recherche, publiés ou non, émanant des établissements d'enseignement et de recherche français ou étrangers, des laboratoires publics ou privés. 


\title{
Carbon Dioxide Reduction to Methanol with a Molecular Cobalt- Catalyst-Loaded Porous Carbon Electrode Assisted by a CIGS Photovoltaic Cell
}

\author{
Ruwen Wang, ${ }^{[\mathrm{a}]}$ Etienne Boutin, ${ }^{[\mathrm{a}][\mathrm{e}]}$ Nicolas Barreau, ${ }^{[\mathrm{b}] \star}$ Fabrice Odobel, ${ }^{[\mathrm{c}]}$ Julien Bonin ${ }^{[\mathrm{a}] \star}$ and Marc \\ Robert $^{[\mathrm{a}][\mathrm{d}] *}$
}

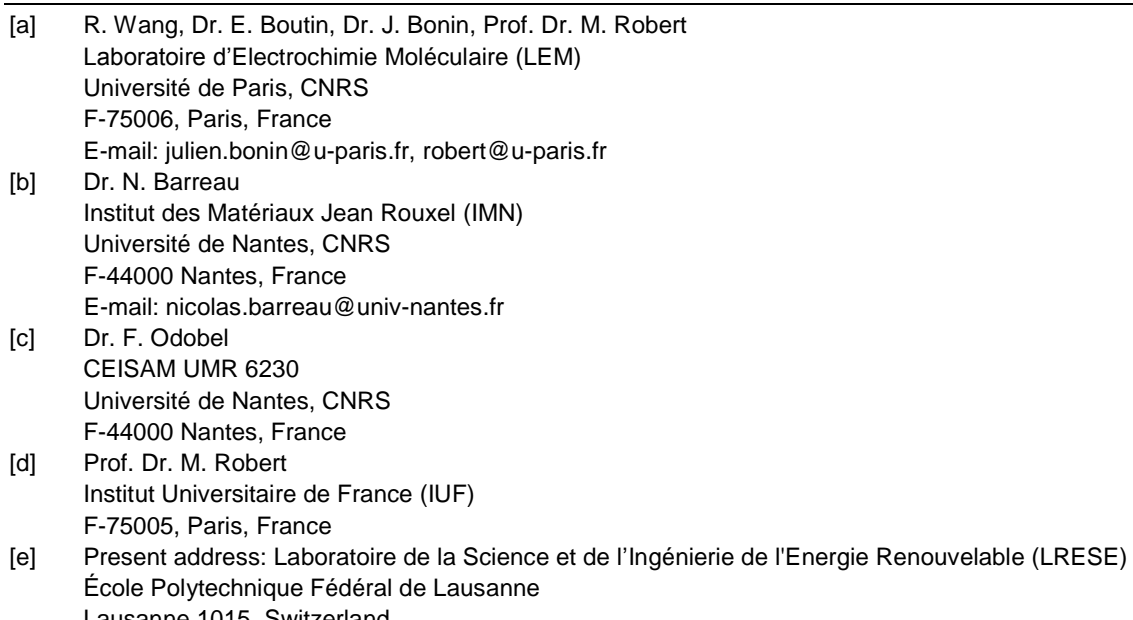

\begin{abstract}
Conversion of $\mathrm{CO}_{2}$ into valuable compounds, including fuels, with renewable energy source and sustainable compounds is a challenge addressed by artificial photosynthesis research. In particular, solar assisted electrochemical (EC) processes, in which electrons are furnished by a photovoltaic (PV) cell is a promising approach. A PV-EC system is described, consisting in a CIGS PV unit linked to a carbon electrode loaded with cobalt phthalocyanine as molecular catalyst, able to achieve the $\mathrm{CO}_{2}$ reduction to $\mathrm{CO}$ and then to methanol in aqueous media with limited bias voltage. Using $\mathrm{CO}$ as starting material, a partial current density of ca. $0.6 \mathrm{~mA} \mathrm{~cm}$ for methanol is obtained at a bias voltage corresponding to a low $240 \mathrm{mV}$ overpotential. Remarkably, the liquid fuel production can be sustained for at least $7 \mathrm{~h}$. Under ideal conditions, the $\mathrm{CO}_{2}-\mathrm{to}-\mathrm{CH}_{3} \mathrm{OH}$ reaction shows a global Faradaic efficiency of $28 \%$.
\end{abstract}

On the path to the production of useful chemicals from $\mathrm{CO}_{2}$ and renewable energy sources, solar induced processes are highly challenging. ${ }^{[1]}$ Converting light energy relies on the creation of charge carriers, i.e. electrons and/or holes, to start redox reactions such as water oxidation and $\mathrm{CO}_{2}$ reduction. Basically, two approaches may be followed. A first one, generally referred to as photochemical, directly uses light to induce the chemical process through the generation of reacting excited states in homogeneous systems ${ }^{[2]}$ or through the formation of electronhole pairs in semiconductors. ${ }^{[3]}$ A second one, combining photophysics and electrochemistry, decouples the light conversion and the chemical process by using, on one side, a photovoltaic (PV) device generating electrons and, on the other side, an electrochemical (EC) cell employing these electrons to drive the chemical reactions of interest. ${ }^{[4]}$ The latter approach presents two key advantages. First, it allows separating both tasks and thus the system can benefit from improvement of both sides independently. Second, the need for a photoactive molecule or material in the electrochemical unit is by-passed, and thus the commonly encountered photodegradation of semiconductors in contact with an electrolyte is avoided. In that context, coupling a PV device to an electrochemical cell (PV-EC, Scheme 1) represents an attractive and emerging approach to utilize solar generated electrons to sustainably activate and convert $\mathrm{CO}_{2}$ in a chemical reactor. ${ }^{[4]}$

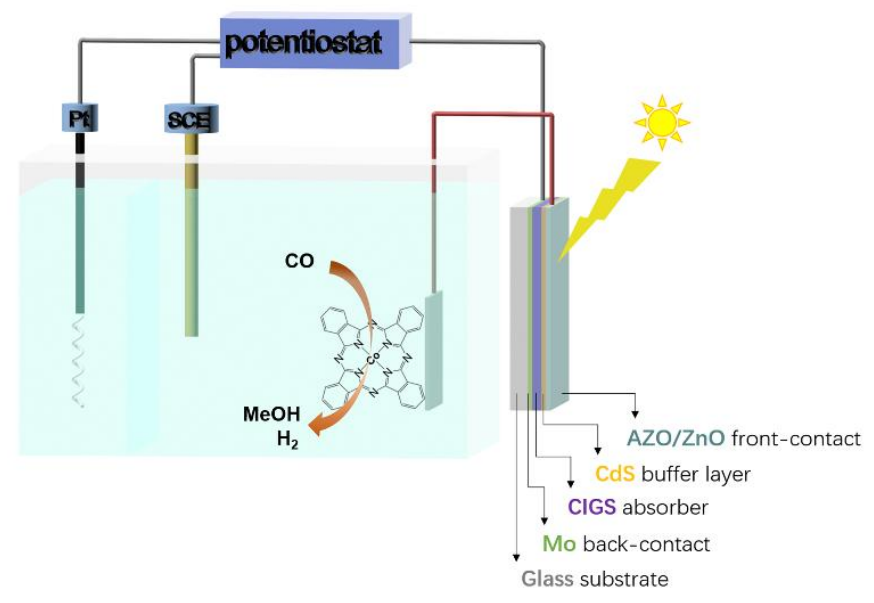

Scheme 1. Scheme of the PV-EC system combining a CIGS PV cell linked to a CoPc loaded carbon paper used as the working electrode in the EC unit for $\mathrm{CO}$ reduction to methanol.

Among the possible $\mathrm{CO}_{2}$ reduction products, molecules which can be directly used as fuels, such as methanol and methane, are of obvious strategic interest. However, their generation requires 6 or 8 electron and proton coupled transfers, respectively, which constitutes a major difficulty. ${ }^{[5]}$ Few studies have been dedicated to the reduction of $\mathrm{CO}_{2}$ to methanol with 
metal complexes. They generally reported trace amounts of the alcohol, with no isotope labeled experiments confirming $\mathrm{CH}_{3} \mathrm{OH}$ originated from $\mathrm{CO}_{2}{ }^{[6]}$ Homogeneous molecular catalysts are however of particular interest since they exhibit high activity and selectivity, possess a tunable structure, allow spectroscopic characterizations and a precise understanding of the reactivity. Notwithstanding, they commonly suffer from limited stability over time, are hardly recyclable and considered as not adequate for up-scaling requirements. Heterogenization of molecular catalyst thus appeared to be the track to follow to circumvent these drawbacks, taking advantage of solid materials as supports. ${ }^{[7]}$ Phthalocyanine $(\mathrm{Pc})$ is a well-known family of catalyst ${ }^{[8]}$ which is industrially used as dyes for painting ${ }^{[9]}$ and are thus particularly appealing as low cost compounds. In an early study, Lieber et al. reported the generation of $\mathrm{CO}$ from $\mathrm{CO}_{2}$ with carbon electrodes modified by absorbed cobalt phthalocyanine (CoPc) at an applied potential of $-1.15 \mathrm{~V}$ vs. SSCE (silver-silver chloride electrode) in a citrate buffer aqueous solution at $\mathrm{pH} 5$, reaching $3.7 \times 10^{5}$ turnover number (TON). ${ }^{[10]}$ The faradaic efficiency (FE) was modest ( 55 to $60 \%$ ) with $\mathrm{H}_{2}$ as the secondary product, with traces of oxalate and formate. This study however highlighted the great gain in stability once CoPc was immobilized on the electrode as compared with the homogeneous case. In a more recent study, ${ }^{[11]}$ Choi et al. showed that a sterically hindered CoPc $\pi$-stacked onto chemically converted graphene and deposited on a carbon paper electrode can achieve the electrochemical reduction of $\mathrm{CO}_{2}$ into $\mathrm{CO}$ with up to $85 \% \mathrm{FE}$ in aqueous solution $(\mathrm{pH} 6.8)$ at a potential of $-0.79 \mathrm{~V} v$ s. RHE. Very recently, ${ }^{[12]}$ Reisner et al. reported the $\mathrm{CO}_{2}$-to-CO conversion on a hybrid electrode composed of a cobalt phthalocyanine complex bearing four phosphonic acid anchoring groups immobilized on mesoporous $\mathrm{TiO}_{2}$. In electrochemical conditions in potassium carbonate buffer solution, $\mathrm{CO}$ was obtained with $85 \%$ selectivity and 1949 TON after $2 \mathrm{~h}$ electrolysis at $-1.09 \mathrm{~V} v \mathrm{vs}$. $\mathrm{NHE}$. Once assembled with a $p$-type silicon photoelectrode, it led to a photocathode that achieved $\mathrm{CO}_{2}$ reduction to $\mathrm{CO}$ in aqueous conditions, under solar illumination and an applied bias of $-0.53 \mathrm{~V}$ vs. SHE, with 939 TON and $66 \%$ selectivity, with $\mathrm{H}_{2}$ as second product. In between these two examples, we demonstrated the first example of the electrochemical reduction of both $\mathrm{CO}_{2}$ and $\mathrm{CO}$ into methanol with $\mathrm{CoPc}$ as molecular catalyst, in the form of a catalytic ink made of multi-walled carbon nanotubes and Nafion then deposited on a carbon paper electrode, in aqueous solutions at ambient temperature and pressure. ${ }^{[13]}$ These results were further confirmed a couple of months later, leading to higher Faradaic efficiency upon high dispersion of the catalyst onto its carbon support. ${ }^{[14]}$ We showed that $\mathrm{CH}_{3} \mathrm{OH}$ is issued from $\mathrm{CO}_{2}$ upon NMR studies using labelled ${ }^{13} \mathrm{CO}_{2}$ as reactant and we identified $\mathrm{CO}$ as an intermediate on the reaction path. Finally, we proposed to decouple the process to maximize efficiency, upon first realizing $\mathrm{CO}_{2}$-to-CO reduction in optimized conditions ( $\mathrm{pH} \mathrm{7.2)} \mathrm{in} \mathrm{a} \mathrm{first}$ electrochemical cell and then using $\mathrm{CO}$ as a reactant in a second cell in basic conditions $(\mathrm{pH} 13)$. A global Faradaic efficiency of $19.5 \%$ and a chemical selectivity of about $7.5 \%$ were calculated. Starting the catalytic process from $\mathrm{CO}$ is indeed advantageous since several robust processes exist to produce $\mathrm{CO}$ with high selectivity ${ }^{[15]}$ and it would allow bypassing the first reduction step of $\mathrm{CO}_{2}$ which is considered as highly difficult. However, the overpotential was large (ca. $740 \mathrm{mV}$ and $910 \mathrm{mV}$ when using $\mathrm{CO}$ and $\mathrm{CO}_{2}$ as reactant, respectively) and $\mathrm{CH}_{3} \mathrm{OH}$ production quickly drops after $2 \mathrm{~h}$. Encouraged by these results, we decided to explore the possibility of feeding the system with electrons coming for an illuminated PV cell so as to lower the applied bias voltage thanks to the photovoltage boost. In this purpose, we employed CIGS (copper indium gallium selenide) materials which possess a strong absorption in the visible range and tunable bandgaps by adjusting the $\mathrm{In} / \mathrm{Ga}$ ratio (Scheme 1, see experimental section for description of the material). ${ }^{[16]}$ Moreover, CIGS-based PV cells recently reached high conversion efficiencies (above 24\%). ${ }^{[17]}$ Following this strategy, we report about the use of a carbon paper porous electrode loaded with a CoPc catalyst and powered by a CIGS PV cell enabling to achieve the $\mathrm{CO}_{2}$ to methanol conversion. Experiments were conducted at ambient pressure and temperature and in aqueous solutions. As previously reported, ${ }^{[13]}$ a catalytic ink was first prepared by mixing CoPc with multiwalled carbon nanotubes (MWCNT) and Nafion resin in a mixture of ethanol and ethylene glycol, to obtain a stable colloidal solution (see Experimental Section for details). Ink deposition onto porous carbon paper was made by drop casting, and the operational catalytic film was obtained after a drying at $100^{\circ} \mathrm{C}$.

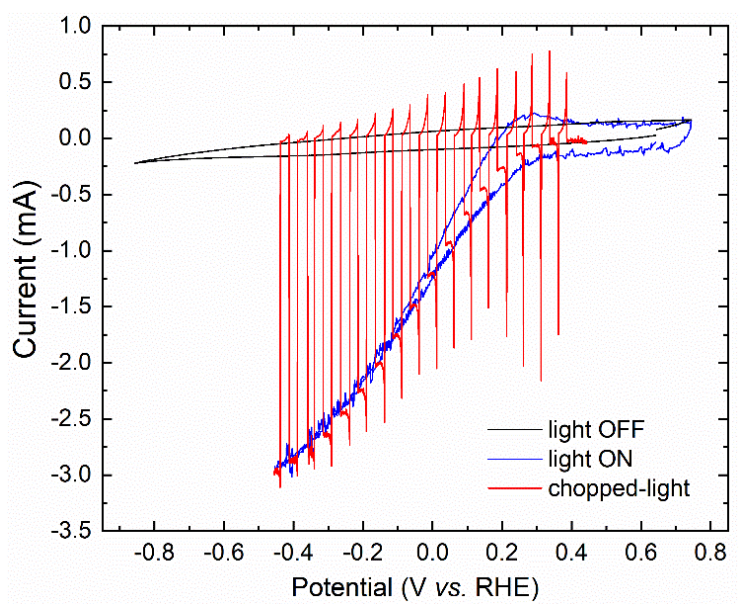

Figure 1. Linear sweep voltammetry of the CIGS (PV) coupled to $\mathrm{CoP} /$ carbon paper (EC) modified electrode with light off (black), light on (blue) and chopped-light (red) in $0.1 \mathrm{M} \mathrm{KHCO}_{3}\left(\mathrm{pH}\right.$ 6.8) electrolyte, under $\mathrm{CO}_{2}$ atmosphere $\left(\mathrm{S}_{\mathrm{CIGS}}=0.9 \mathrm{~cm}^{2}\right.$ and $\left.\mathrm{S}_{\text {carbon paper }}=0.5 \mathrm{~cm}^{2}\right)$.

We first explored the ability of the PV-EC assembly to drive the reduction of $\mathrm{CO}_{2}$. In Figure 1, linear sweep voltammetry (LSV) measurements show that no catalytic wave was observed in the absence of illumination, illustrating the need for photons and photovoltage from the CIGS cell to activate the catalyst and to reach the required potential to reduce $\mathrm{CO}_{2}$. Moreover, choppedlight experiments clearly showed that a significant 2-3 mA photocurrent (corresponding to 4-6 $\mathrm{mA} \mathrm{cm}$-2 relatively to the carbon electrode surface) was obtained upon illumination, associated with a typical photovoltage from the CIGS cell of $c a$. $660 \mathrm{mV}$. Typical profile (for example, Fig. 1, red signal) is generally explained as follows: the intensity of the current spike is consistent over the potential range and represents the reduction of the holes from the large quantity of electron/hole pairs that are created upon sudden light irradiation. At rather positive potential, excited electrons do not reach the surface since there is no or slow catalysis, they thus recombine quickly 
with newly formed holes and the current concomitantly exponentially decays. At more negative potential, exited electrons are energetic enough to reach the interface and to participate to the catalytic process. The current decay is less pronounced and spike is smaller: all exited electrons are now collected and the reaction is only limited by the photovoltaic current. As can be seen in Table 1, entries 1-2, the main reduction product was $\mathrm{CO}$ with small amounts of $\mathrm{H}_{2}$ and methanol. Based on our previous studies showing that $\mathrm{CO}$ is a key intermediate to further reduced compounds, ${ }^{[13,15,18]}$ we then explored the direct use of $\mathrm{CO}$ as starting reactant (Table 1, entries 3-8) in basic conditions, as described in our initial electrochemical study.[18]

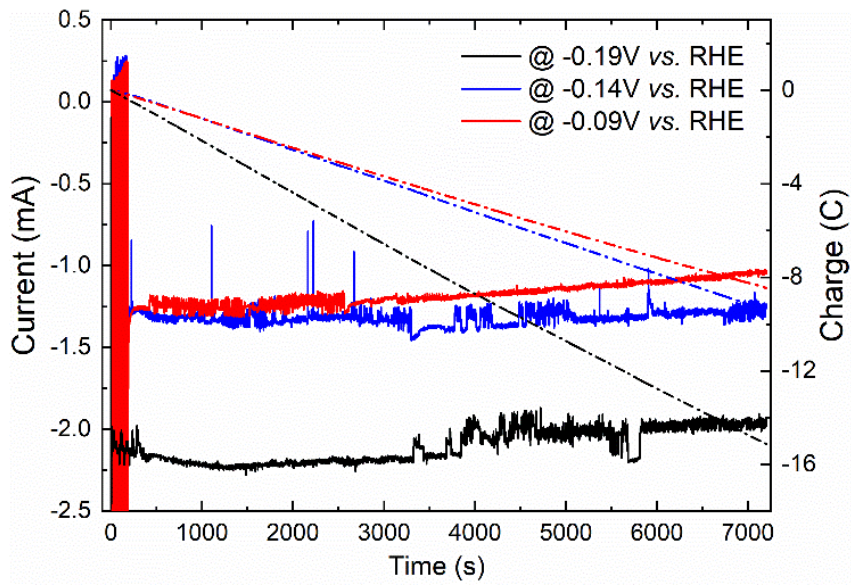

Figure 2. Current (solid line) and charge (dash-dot line) measured during controlled potential photo-electrolysis at -0.09 (red), -0.14 (blue) and -0.19 (black) V vs. RHE applied bias of the illuminated CIGS (PV) coupled to $\mathrm{CoPc} /$ carbon paper (EC) assembly in $0.1 \mathrm{M} \mathrm{KOH}(\mathrm{pH} 13)$ electrolyte, under $\mathrm{CO}$ atmosphere, with $\mathrm{S}_{\mathrm{CIGS}}=0.9 \mathrm{~cm}^{2}$ and $\mathrm{S}_{\text {carbon paper }}=0.5 \mathrm{~cm}^{2}$.

Figure 2 shows the evolution of current with time during controlled potential photo-electrolysis (CPPE) under CO atmosphere at $\mathrm{pH} 13$ and different applied bias voltage. Note that during the first $200 \mathrm{~s}$, a chopped-light experiment was conducted to check for the photo-response of the system, which explains the shape of the current signal (same is true for Figures 3). Very interestingly, methanol was produced in significant amount, further illustrating that the formation of $\mathrm{CO}$ is an intermediary step to further reduction. After $2 \mathrm{~h}$ of CPE, a quite stable current of $1.18,1.32$ and $2.10 \mathrm{~mA}$ was observed at bias voltage of $-0.09,-0.14$ and $-0.19 \mathrm{~V} v s$. RHE respectively (Table 1 entries 3-5). The more negative the bias voltage the higher the total, with $\mathrm{H}_{2}$ as main product and in increasing proportion. An optimal $19 \% \mathrm{FE}$ for methanol was obtained at $-0.14 \mathrm{~V}$ vs. RHE (Table 1, entry 4). At a positive bias voltage of $+0.01 \mathrm{~V} v$ s. RHE, no current was observed (Table 1, entry 6) showing that no $\mathrm{CO}$ conversion occurred. Isotope labelled experiments under ${ }^{13} \mathrm{CO}$ atmosphere were conducted and methanol analysis by $\mathrm{NMR}^{[19]}$ (Figure 4) indeed confirmed that $\mathrm{CH}_{3} \mathrm{OH}$ originated from $\mathrm{CO}$, with full splitting of the proton signal (methyl group).

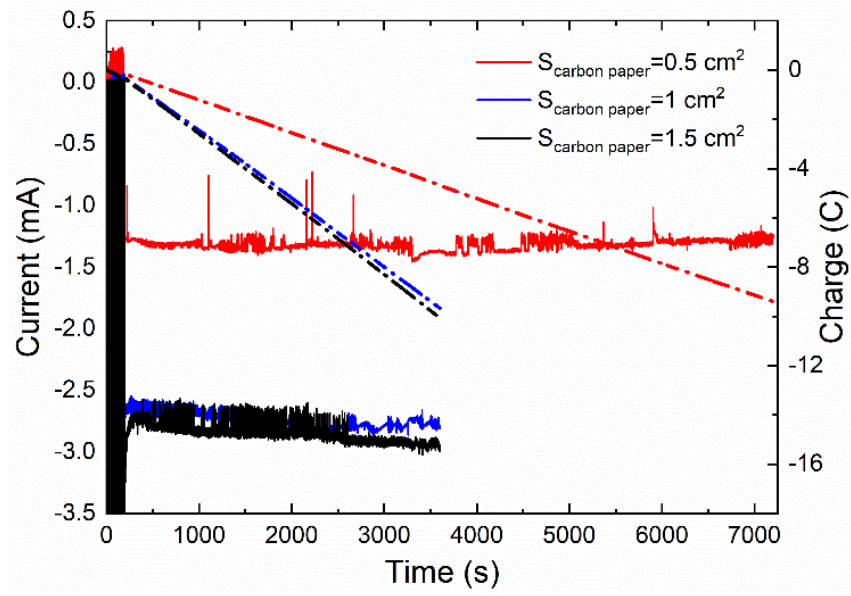

Figure 3. Current (solid line) and charge (dash-dot line) measured during controlled potential photo-electrolysis at $E_{\text {applied }}=-0.14 \mathrm{~V}$ vs. RHE of the illuminated CIGS (PV) coupled to CoPc/carbon paper (EC) assembly in $0.1 \mathrm{M}$ $\mathrm{KOH}\left(\mathrm{pH}\right.$ 13) electrolyte, under $\mathrm{CO}$ atmosphere, with $\mathrm{S}_{\mathrm{CIGS}}=0.9 \mathrm{~cm}^{2}$ and $\mathrm{S}_{\text {carbon paper }}=0.5$ (red), 1 (blue) and 1.5 (black) $\mathrm{cm}^{2}$.

The influence of the surface area of the carbon paper electrode was investigated. At a fixed CIGS surface area of $0.9 \mathrm{~cm}^{2}$, three carbon paper electrode area, i.e. $0.5,1$ and $1.5 \mathrm{~cm}^{2}$ were tested (Figure 3). While current was multiplied by a factor of ca. 2 when going from 0.5 (Table 1, entry 4) to $1 \mathrm{~cm}^{2}$ (entry 7), almost no current increase was observed with a further increase to $1.5 \mathrm{~cm}^{2}$ (entry 8). This seems to indicate that an insufficient amount of electrons was provided by the CIGS PV cell to fully feed an electrode of such area.

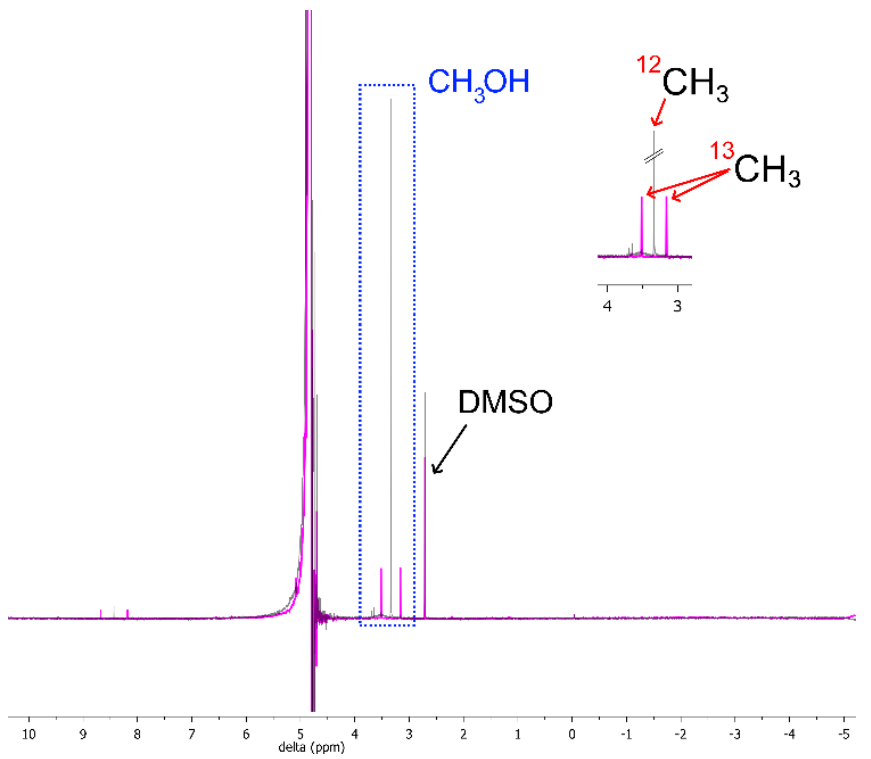

Figure 4. ${ }^{1} \mathrm{H}$ NMR spectrum showing the characteristic doublet signal of methanol (violet, $\mathrm{CH}_{3}$ protons, $\delta=3.16$ and $3.52 \mathrm{ppm}$, see inset) due to ${ }^{13} \mathrm{C}$, measured after $1 \mathrm{~h} \mathrm{CPE}$ at $E_{\text {applied }}=-0.14 \mathrm{~V}$ vs. RHE of the illuminated CIGS (PV) coupled to CoPc/carbon paper (EC) assembly in $0.1 \mathrm{M} \mathrm{KOH}(\mathrm{pH} 13)$ electrolyte, under ${ }^{13} \mathrm{CO}$ atmosphere, with $\mathrm{S}_{\mathrm{CIGS}}=0.3 \mathrm{~cm}^{2}$ and $\mathrm{S}_{\text {carbon paper }}=1$ $\mathrm{cm}^{2}$. A reference spectra obtained upon electrolysis under ${ }^{12} \mathrm{CO}$ atmosphere is shown in light grey (the singlet due to $\mathrm{CH}_{3}$ protons of $\mathrm{CH}_{3} \mathrm{OH}$ appears at $\delta=3.34 \mathrm{ppm})$. 
Control experiments were conducted under argon atmosphere (Table 1, entry 9) and we observed no $\mathrm{CO}$ or methanol production, only $\mathrm{H}_{2}$ being detected in the similar amount than under $\mathrm{CO}$ atmosphere (entry 7), suggesting an independent reaction pathway to hydrogen.

To evaluate the robustness of the PV-EC assembly and the evolution of the products formed with time, we conducted an extended CPE under $\mathrm{CO}$ atmosphere for $7 \mathrm{~h}$, with periodic analysis of the both liquid and gaseous reduction products (Table 2). As can be seen in Figure 5, current, albeit a little fluctuating, remained quite constant over the electrolysis course, at a mean value of $-1.75 \mathrm{~mA}$, together with a linear evolution of the charge passed. Gas chromatography and ${ }^{1} \mathrm{H}$ NMR analysis of the products formed revealed that, first, FE for methanol was progressively lowered from $16 \%$ after the first CPE hour to $10 \%$ at $7 \mathrm{~h} \mathrm{CPE}$ (Figure 6). Hydrogen FE was concomitantly increasing from 65 to $70 \%$. Interestingly, this decay of FE for methanol starts after three hours of CPE, which is consistent with our previous report showing a couple of hours stability for methanol production. ${ }^{[13]}$ Cumulated molar concentration of methanol in the reaction mixture evolved linearly over the whole CPE course up to a total amount of $2.4 \mathrm{mM}$. Remarkably, the catalytic reaction occurs at a very low overpotential.

To further characterize the electrode durability, X-ray photoelectron spectroscopy (XPS) and inductively coupled plasma-optical emission spectroscopy (ICP-OES) measurements were conducted before, during $(2 \mathrm{~h})$ and at the end $(7 \mathrm{~h}$ ) of the electrolysis. XPS spectrum (Fig. S4a and Table $\mathrm{S} 1$ ) in the $\mathrm{N}$ 1s region exhibited three separated peaks attributed to the pyridinic, pyrrolic and oxidized $\mathrm{N}$ atoms at 398.5, 399.96, and $402.0 \mathrm{eV}$ binding energy, respectively. The spectrum in the Co $2 p$ region (Fig. S4b) showed two peaks centered at 781.1 $\left(2 p_{3 / 2}\right)$ and $796 \mathrm{eV}\left(2 p_{1 / 2}\right)$, respectively. Both confirm the presence of the CoPc catalyst on the electrode surface. Along the course of electrolysis, both pyridinic $\mathrm{N}$ and Co gradually decreased, by a final factor of ca. 3 , suggesting CoPc desorption rather than decomposition since catalytic activity is maintained.
ICP measurements confirmed such interpretation with a similar decrease in the cobalt amount on the surface over the electrolysis course (Table S2).

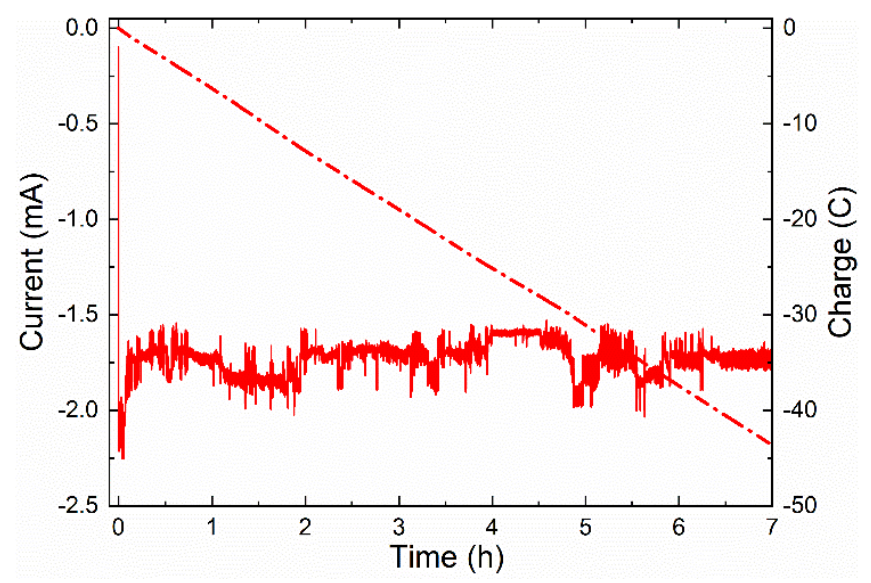

Figure 5. Current (solid line) and charge (dash-dot line) measured during extended controlled potential photo-electrolysis at $-0.14 \mathrm{~V}$ vs. RHE applied bias of the illuminated CIGS (PV) coupled to CoPc/carbon paper (EC) assembly in $0.1 \mathrm{M} \mathrm{KOH}\left(\mathrm{pH} \mathrm{13)}\right.$ electrolyte, under $\mathrm{CO}$ atmosphere, with $\mathrm{S}_{\text {CIGS }}$ $=0.3 \mathrm{~cm}^{2}$ and $S_{\text {Carbon paper }}=1 \mathrm{~cm}^{2}$.

Finally, since the same catalyst can be used for reducing first $\mathrm{CO}_{2}$ to $\mathrm{CO}$, and then $\mathrm{CO}$ to methanol, $\mathrm{pH}$ and electrode potential could be adjusted to maximize each partial reduction process. The first $\mathrm{CO}_{2}$-to- $\mathrm{CO}$ pure electrochemical step can be achieved with typical 95\% Faradaic efficiency in neutral $\mathrm{pH}$ conditions as already shown ${ }^{[15]}$ while the second step may be achieved with a PV-EC cell as described in this study. From the total number of transferred electrons, a global Faradaic efficiency of $28 \%$ is calculated and the chemical selectivity is equal to ca. $11.6 \%$ (Fig. S3).

Table 1. PV-EC $\mathrm{CO}_{2}$ and $\mathrm{CO}$ electrochemical reduction performance with $\mathrm{CoPc}$ decorated carbon paper electrode powered by a CIGS PV cell.

\begin{tabular}{|c|c|c|c|c|c|c|c|c|c|c|c|c|c|c|c|}
\hline \multirow[b]{2}{*}{ Entry } & \multirow{2}{*}{ Substrate } & \multirow{2}{*}{ Electrolyte } & \multirow{2}{*}{$\begin{array}{l}\text { Time } \\
\text { (h) }\end{array}$} & \multirow{2}{*}{$\begin{array}{l}\text { Eapplied } \\
(\mathrm{V} \text { vs. } \\
\mathrm{RHE})\end{array}$} & \multirow{2}{*}{$\begin{array}{l}\mathrm{S}_{\text {carbon }} \\
\text { paper } \\
\left(\mathrm{cm}^{2}\right)\end{array}$} & \multirow{2}{*}{$\begin{array}{l}\mathrm{S}_{\mathrm{CIGS}} \\
\left(\mathrm{cm}^{2}\right)\end{array}$} & \multirow{2}{*}{$\begin{array}{l}\mathrm{m}_{\text {cat. }}: \\
\mathrm{m}_{\text {MCNTs }}\end{array}$} & \multirow{2}{*}{$\begin{array}{l}\eta^{\mathrm{a}} \\
(\mathrm{mV})\end{array}$} & \multirow{2}{*}{$\begin{array}{l}i_{\text {total }} \\
(\mathrm{mA})\end{array}$} & \multicolumn{2}{|c|}{$\mathrm{CH}_{3} \mathrm{OH}$} & \multicolumn{2}{|c|}{$\mathrm{CO}$} & \multicolumn{2}{|c|}{$\mathrm{H}_{2}$} \\
\hline & & & & & & & & & & $\begin{array}{l}F E \\
(\%)\end{array}$ & $\begin{array}{l}i \\
(\mathrm{~mA})\end{array}$ & $\begin{array}{l}F E \\
(\%)\end{array}$ & $\begin{array}{l}i \\
(\mathrm{~mA})\end{array}$ & $\begin{array}{l}F E \\
(\%)\end{array}$ & $\begin{array}{l}i \\
(\mathrm{~mA})\end{array}$ \\
\hline 1 & \multirow{2}{*}{$\mathrm{CO}_{2}$} & \multirow{2}{*}{$\begin{array}{l}0.1 \mathrm{M} \mathrm{KHCO}_{3} \\
\mathrm{pH} 6.8\end{array}$} & 1 & -0.36 & 0.5 & 0.9 & $1: 15$ & 390 & 2.35 & 1.2 & 0.03 & 105 & 2.35 & 7 & 0.16 \\
\hline 2 & & & 2 & -0.46 & 0.5 & 0.9 & $1: 15$ & 490 & 2.83 & 0.3 & 0.01 & 108 & 2.83 & 8 & 0.23 \\
\hline 3 & \multirow{6}{*}{$\mathrm{CO}$} & \multirow{7}{*}{$\begin{array}{l}0.1 \mathrm{M} \mathrm{KOH} \\
\mathrm{pH} 13\end{array}$} & 2 & -0.19 & 0.5 & 0.9 & $1: 15$ & 290 & 2.10 & 12 & 0.25 & - & - & 87 & 1.83 \\
\hline 4 & & & 2 & -0.14 & 0.5 & 0.9 & $1: 15$ & 240 & 1.32 & 19 & 0.25 & - & - & 65 & 0.86 \\
\hline 5 & & & 2 & -0.09 & 0.5 & 0.9 & $1: 15$ & 190 & 1.18 & 8.5 & 0.10 & - & - & 60 & 0.71 \\
\hline 6 & & & 2 & +0.01 & 0.5 & 0.9 & $1: 15$ & 90 & - & 0 & - & - & - & - & - \\
\hline 7 & & & 1 & -0.14 & 1 & 0.9 & $1: 15$ & 240 & 2.75 & 21 & 0.58 & - & - & 73 & 2.01 \\
\hline 8 & & & 1 & -0.14 & 1.5 & 0.9 & $1: 15$ & 240 & 2.85 & 15 & 0.43 & - & - & 78 & 2.22 \\
\hline 9 & $\mathrm{Ar}$ & & 1 & -0.14 & 1 & 0.9 & $1: 15$ & 240 & 3.39 & - & - & - & - & 73 & 2.47 \\
\hline
\end{tabular}

a. $\eta$ is the overpotential for the considered reaction and is defined as: $\eta=E^{0^{\prime}}$ (reactant/product) - $E_{\text {applied }}$ (see Supporting Information for calculation of $E^{0}\left(\mathrm{CO} / \mathrm{CH}_{3} \mathrm{OH}\right)$ at $\left.\mathrm{pH} 13\right)$. 


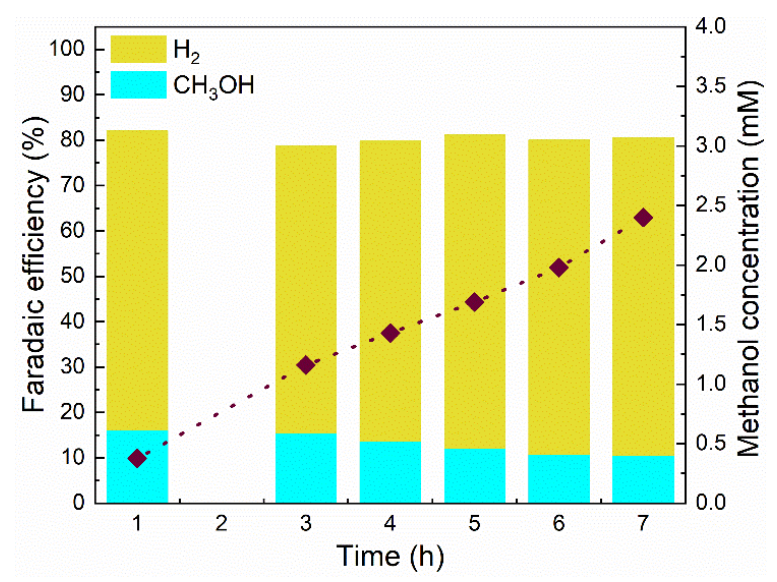

Figure 6. Evolution of the faradaic efficiency in $\mathrm{H}_{2}$ (green) and methanol (blue) and of methanol concentration (wine diamonds) during the extended controlled potential photo-electrolysis at $E_{\text {applied }}=-0.14 \mathrm{~V} v s$. RHE of the illuminated CIGS (PV) coupled to CoPc/carbon paper (EC) assembly in $0.1 \mathrm{M} \mathrm{KOH}(\mathrm{pH}$ 13) electrolyte, under $\mathrm{CO}$ atmosphere. $S_{\mathrm{CIGS}}=0.3 \mathrm{~cm}^{2}$ and $S_{\text {Carbon paper }}=1 \mathrm{~cm}^{2}$.

Overall, we have showed very promising results on the combination of a CIGS PV cell with a molecular catalyst deposited on a carbon electrode to achieve the solar assisted $\mathrm{CO}_{2}$ to $\mathrm{CO}$ to methanol reduction in aqueous media. The origin of carbon products was asserted by isotope labelled experiments. In this PV-EC system, the electrochemical moiety is only based on abundant elements (carbon, cobalt) and is operational at ambient pressure and temperature, the employed molecular catalyst belonging to an already industrially used class of compounds, i.e. phthalocyanines. Thanks to the remarkable efficiency of the CIGS unit, able to furnish a large photovoltage and thus to feed the EC unit, the formation of $\mathrm{mM}$ amounts of methanol was reached after few hours of CPPE at very moderate applied bias. First stability tests are highly encouraging, having no great loss of activity during several hours even if progressive catalyst desorption occurs on the long term. Our results indicate that the performance of the system depend on the surface area matching between the PV cell and the electrode. More work is under way to gain both in understanding and on productivity.

Table 2. Current $(I)$ and faradaic efficiency $(\mathrm{FE})$ during controlled potential photo-electrolysis at $E_{\text {applied }}=-0.14 \mathrm{~V}$ vs. RHE, with CoPc:MWCNT mass ratio of $1: 15$, in $0.1 \mathrm{M} \mathrm{KOH}(\mathrm{pH} 13)$ electrolyte, under $\mathrm{CO}$ atmosphere, with $\mathrm{S}_{\mathrm{CIGS}}=$ $0.3 \mathrm{~cm}^{2}$ and $\mathrm{S}_{\text {Carbon paper }}=1 \mathrm{~cm}^{2}$.

\begin{tabular}{lccccc}
\hline \multicolumn{5}{c}{} & \multicolumn{3}{c}{$\mathrm{CH}_{3} \mathrm{OH}$} & \multicolumn{2}{c}{$\mathrm{H}_{2}$} \\
Time $(\mathrm{h})$ & $\begin{array}{l}i_{\text {total }} \\
(\mathrm{mA})\end{array}$ & $\begin{array}{l}\mathrm{FE} \\
(\%)\end{array}$ & $\begin{array}{l}i \\
(\mathrm{~mA})\end{array}$ & $\begin{array}{c}\mathrm{FE} \\
(\%)\end{array}$ & $\begin{array}{l}i \\
(\mathrm{~mA})\end{array}$ \\
\hline 1 & 1.74 & 16.2 & 0.28 & 65.9 & 1.15 \\
3 & 1.75 & 15.6 & 0.27 & 63.3 & 1.11 \\
4 & 1.74 & 13.6 & 0.24 & 66.2 & 1.15 \\
5 & 1.73 & 12.1 & 0.21 & 69.2 & 1.2 \\
6 & 1.73 & 10.7 & 0.19 & 69.3 & 1.20
\end{tabular}

\begin{tabular}{llllll}
7 & 1.73 & 10.5 & 0.18 & 70.2 & 1.21 \\
\hline
\end{tabular}

\section{Experimental Section}

Chemicals and materials. Cobalt phthalocyanine (CoPc, $\beta$ form, 97\% dye content, Sigma Aldrich), ethylene glycol (EG, reagent plus > 99\%, Sigma Aldrich), ethanol (EtOH, Merck, analysis grade), Nafion(C) (perfluorinated ion exchange powder, 5 wt \% solution in low aliphatic alcohol $/ \mathrm{H}_{2} \mathrm{O}$, Sigma Aldrich, diluted to $2.9 \%$ with ethanol) were used without further purification. Multiwalled carbon nanotubes (MWCNTs, 6-9 nm diameter, $5 \mu \mathrm{m}$ length, > 95\% Carbon, Sigma Aldrich), carbon paper (Toray Carbon Paper, TGPH-60, Alfa Aesar) were used as received. $\mathrm{CO}_{2},{ }^{12} \mathrm{CO}$ and Argon were supplied by Air Liquide, whereas ${ }^{13} \mathrm{CO}$ was supplied by Sigma-Aldrich.

Preparation of the catalytic ink. $3 \mathrm{mg}$ of MWCNTs were dispersed in $2 \mathrm{~mL} \mathrm{EG/EtOH} \mathrm{1:1} \mathrm{(v/v)} \mathrm{mixture} \mathrm{followed} \mathrm{by} 30 \mathrm{~min}$ sonication. $1 \mathrm{mg} \mathrm{CoPc}$ was dissolved in $1 \mathrm{~mL} E G / E t O H$ mixture and then $200 \mu \mathrm{L}$ was added to the MWCNTs suspension. The suspension was further sonicated for $30 \mathrm{~min}$. Finally, Nafion was added $(2.9 \%, 30 \mu \mathrm{L})$ and the complete mixture was sonicated to obtain the final catalytic ink. $75 \mu \mathrm{L}$ ink was then drop casted on carbon paper to obtain the working electrode.

CIGS cell characterizations. $\mathrm{Cu}(\mathrm{In}, \mathrm{Ga}) \mathrm{Se}_{2}$ (CIGS) thin films were synthesized following a modified so called CuPRO-process, as described elsewhere. ${ }^{[20]}$ The gallium to indium ratio within the films was large enough to yield an absorber band gap of $1.6 \mathrm{eV}$, deduced from absorption threshold of the external quantum efficiency, Fig. S1. The glass/Mo/CIGSe structures were covered with n-type CdS, deposited by chemical bath deposition (CBD), and sputtered $\mathrm{ZnO} / \mathrm{ZnO}: \mathrm{Al}$ bilayer. For the sample operated herein, no electron collection grids were applied to the solar cells, which is at the origin of the limited device fill factor (FF). The typical photovoltaic parameters deduced from currentvoltage characteristics (Fig. S2) range like: Voc $=680-700 \mathrm{mV}$, $\mathrm{Jsc}=18.0-18.5 \mathrm{~mA} / \mathrm{cm}^{2}, \mathrm{FF}=58-62 \%$ leading to photovoltaic conversion efficiency of $\sim 8 \%$.

Electrode characterizations. The composition of the CoPc loaded porous carbon electrode was determined by X-ray photoelectron spectroscopy (XPS) recorded on an ESCALAB 250 spectrometer (Thermo Sci.) accompanied by a microfocalized X-ray source (Ka Al $1486.6 \mathrm{eV}$ ) and a double monochromator. Inductively coupled plasma-optical emission spectroscopy (ICP-OES) was conducted with an ICAP 6300 ICP-OES CID spectrometer (Thermo Sci.). A test was performed with a RACHID detector including a diode array, a peristaltic pump, and argon plasma (analyzes present at $50 \mathrm{rpm}, 1150 \mathrm{~W}$ ). The CoPc MWCNTs carbon paper electrode was immersed in 2 $\mathrm{mL} 69 \%$ nitride acid for $20 \mathrm{~h}$ and then diluted to $20 \mathrm{~mL}$ solution to get the sample for ICP measurement.

Controlled potential electrolysis. PV-EC experiments were performed with a PGSTAT $302 \mathrm{~N}$ Autolab potentiostatgalvanostat. The cell volume was $32.5 \mathrm{~mL}$, containing $6 \mathrm{~mL}$ of electrolyte $(7 \mathrm{ml}$ for the $7 \mathrm{~h} \mathrm{CPE})$. Solutions were systematically purged with Ar for 15 min to remove atmospheric $\mathrm{O}_{2}$, and then saturated with the gas of interest by bubbling more than $20 \mathrm{~min}$ before any measurement. Irradiation was simulated with a 150- 
W xenon lamp (Oriel Instrument) with light source positioned at $5 \mathrm{~cm}$ from the PV cell.

The external CIGS PV cell (front) was connected in series with a carbon paper electrode. Front (-) and back (+) lateral contacts of the cell were taken on AZO and Mo layers with coper wire, respectively. Regarding the EC part, a standard three-electrode configuration was employed with a Pt mesh as the counter electrode, which was separated from the working compartment by a glass frit bridge filled with the same electrolyte, and a saturated calomel electrode (SCE) as reference electrode (Ref). Potentials were measured relative to a saturated calomel electrode (SCE) as Ref and converted into relative hydrogen electrode (RHE) using Eq. (1):

$E(\mathrm{~V}$ vs. $\mathrm{RHE})=E(\mathrm{~V}$ vs. SCE $)+0.242+0.059 \times \mathrm{pH}$

Reduction products analysis. Gaseous products evolution in the sample headspace during PV-EC experiments were followed with an Agilent Technologies 7820A gas chromatography (GC) system equipped with a thermal conductivity detector and a CPCarboPlot P7 capillary column $(27.46 \mathrm{~m}$ in length and $25 \mu \mathrm{m}$ internal diameter), with argon as carrier gas $\left(9.5 \mathrm{~mL} \mathrm{~min}^{-1}\right.$ constant flow, 0.5 bar constant pressure). Temperature was set to $150{ }^{\circ} \mathrm{C}$ for the detector and to $34{ }^{\circ} \mathrm{C}$ for the oven. Injection was performed with a $250 \mu \mathrm{L}$ Hamilton gas-tight sample-lock syringe. $\mathrm{CO}$ and $\mathrm{H}_{2}$ molar amounts were determined through the conversion of GC peaks area into mole using individual calibration curves. Liquid phase products were analyzed with a Bruker AC $400 \mathrm{MHz}$ NMR, for which tubes were filled with 480 $\mu \mathrm{L}$ solution: $392 \mu \mathrm{L}$ of the sample solution, $40 \mu \mathrm{L}$ of $4 \mathrm{mM}$ DMSO (Sigma Aldrich, anhydrous $99.8 \%$ ) as internal standard and $48 \mu \mathrm{L}$ of $\mathrm{D}_{2} \mathrm{O}$ (Sigma Aldrich, $99 \%$ atoms $\mathrm{D}$ ) as a lock solvent. A minimum of 128 scans were accumulated with water pre-saturation method and using a relaxation time of $25 \mathrm{~s}$. Quantification was made relative to the DMSO peak.

\section{Acknowledgements}

R.W. thanks the China Scholarship Council for her PhD fellowship (CSC student number 201806890019). Partial financial support from the French National Agency for Research (ANR-16-CE05-0010-01), from the Institut Universitaire de France (IUF), and from Région des Pays de la Loire (project "Hybrid Z-scheme," program LUMOMAT) is also gratefully acknowledged.

\section{Conflict of Interest}

The authors declare no conflict of interest.

Keywords: $\mathrm{CO}_{2}$ reduction $\cdot$ methanol $\cdot$ molecular supported catalysis $• \mathrm{CIGS} \cdot$ electrochemical catalysis

[1] M. T. Spitler, M. A. Modestino, T. G. Deutsch, C. X. Xiang, J. R. Durrant, D. V. Esposito, S. Haussener, S. Maldonado, I. D. Sharp, B. A. Parkinson, D. S. Ginley, F. A. Houle, T. Hannappel, N. R. Neale, D. G. Nocera, P. C. Mclntyre, Sustain. Energ. Fuels 2020, 4, 985-995.

[2] aK. A. Grice, Coord. Chem. Rev. 2017, 336, 78-95; bH. Rao, C.-H. Lim, J. Bonin, G. M. Miyake, M. Robert, J. Am.
Chem. Soc. 2018, 140, 17830-17834; cH. Rao, L. C. Schmidt, J. Bonin, M. Robert, Nature 2017, 548, 74-77. [3] aC. Peng, G. Reid, H. Wang, P. Hu, J. Chem. Phys. 2017, 147, 030901; bB. Kumar, M. Llorente, J. Froehlich, T. Dang, A. Sathrum, C. P. Kubiak, Annu. Rev. Phys. Chem. 2012, 63, 541-569.

[4] aW.-H. Cheng, M. H. Richter, I. Sullivan, D. M. Larson, C. Xiang, B. S. Brunschwig, H. A. Atwater, ACS Energy Lett. 2020, 5, 470-476; bC. E. Creissen, M. Fontecave, Adv. Energy Mater. Early view, 2002652.

[5] aK. Kobayashi, K. Tanaka, Phys. Chem. Chem. Phys. 2014, 16, 2240-2250; bJ. Resasco, A. T. Bell, Trends in Chemistry 2020, 2, 825-836; cW. Zhang, Y. Hu, L. Ma, G. Zhu, Y. Wang, X. Xue, R. Chen, S. Yang, Z. Jin, Adv. Sci. 2018, 5, 1700275.

[6] aK. Kusuda, R. Ishihara, H. Yamaguchi, I. Izumi, Electrochim. Acta 1986, 31, 657-663; bM. Abdinejad, A. Seifitokaldani, C. Dao, E. H. Sargent, X.-a. Zhang, H. B. Kraatz, ACS Appl. Energy Mater. 2019, 2, 1330-1335; cS. Kapusta, N. Hackerman, J. Electrochem. Soc. 1984, 131, 1511-1514.

[7] aM. E. Louis, T. G. Fenton, J. Rondeau, T. Jin, G. Li, Comments Inorg. Chem. 2016, 36, 38-60; bS. Zhang, Q. Fan, R. Xia, T. J. Meyer, Acc. Chem. Res. 2020, 53, 255264.

[8] J. H. Zagal, S. Griveau, J. F. Silva, T. Nyokong, F. Bedioui, Coord. Chem. Rev. 2010, 254, 2755-2791.

[9] S. Q. Lomax, Stud. Conserv, 2005, 50, 19-29.

[10] C. M. Lieber, N. S. Lewis, J. Am. Chem. Soc. 1984, 106 5033-5034.

[11] J. Choi, P. Wagner, S. Gambhir, R. Jalili, D. R. MacFarlane, G. G. Wallace, D. L. Officer, ACS Energy Lett. 2019, 4, 666-672.

[12] S. Roy, M. Miller, J. Warnan, J. J. Leung, C. D. Sahm, E. Reisner, ACS Catal. 2021, 11, 1868-1876.

[13] E. Boutin, M. Wang, J. C. Lin, M. Mesnage, D. Mendoza, B. Lassalle-Kaiser, C. Hahn, T. F. Jaramillo, M. Robert, Angew. Chem., Int. Ed. 2019, 58, 16172-16176.

[14] Y. Wu, Z. Jiang, X. Lu, Y. Liang, H. Wang, Nature 2019 575, 639-642.

[15] E. Boutin, L. Merakeb, B. Ma, B. Boudy, M. Wang, J. Bonin, E. Anxolabéhère-Mallart, M. Robert, Chem. Soc. Rev. 2020, 49, 5772-5809.

[16] M. Asaduzzaman, M. Hasan, A. N. Bahar, Springerplus 2016, 5, 578.

[17] aN. E. I. Boukortt, S. Patanè, Optik 2020, 218, 165240; bN Mufti, T. Amrillah, A. Taufiq, Sunaryono, Aripriharta, M. Diantoro, Zulhadjri, H. Nur, Sol. Energy 2020, 207, 1146 1157.

[18] H. Rao, L. C. Schmidt, J. Bonin, M. Robert, Nature 2017, 548, 74-77.

[19] T. Chatterjee, E. Boutin, M. Robert, Dalton Trans. 2020 49, 4257-4265.

[20] P. Tsoulka, A. Rivalland, L. Arzel, N. Barreau, Thin Solid Films 2020, 709, 138224. 


\section{Entry for the Table of Contents}

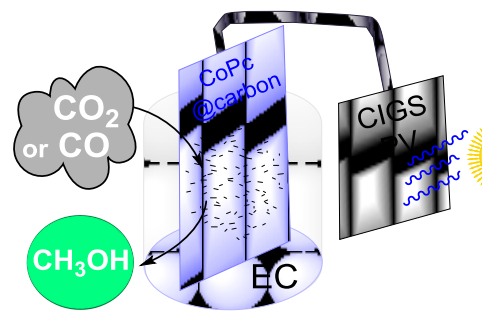

A combination of a CIGS PV cell with a molecular cobalt catalyst loaded on a porous carbon electrode was able to achieve solar assisted $\mathrm{CO}_{2}$ reduction to $\mathrm{CO}$ and then to methanol. Using $\mathrm{CO}$ as a reactant, a partial current density for alcohol production close to $0.6 \mathrm{~mA} \mathrm{~cm}$-2 was obtained at low overpotential (ca. $240 \mathrm{mV}$ ). This PV-EC system works at ambient conditions and in aqueous conditions, with excellent stability over time. 